\title{
Influence of Inputs on outcomes of Educational Attainment in Secondary Schools in Kenya.
}

\author{
Kurgat J. Joyce \\ Moi University, School of EducationP.O Box 3900Eldoret, Kenya
}

\begin{abstract}
The purpose of this study was to determine the influence of inputs on the outcomes of educational attainment. The specific objectives of the study are; to determine the influence of FDSE subsidy on enrolment, to establish the influence of FDSE subsidy on retention, to assess the influence of FDSE subsidy on transition and to determine the influence of FDSE subsidy on equity. The study adopted a mixed method design. The target population included education officials and principals of high schools. The respondents were selected using purposive, and simple random sampling technique and the instruments for data collection were questionnaire and interview schedule. Data was analyzed using descriptive statistics and inferential statistics. The study findings revealed that there is a relationship between the FDSE subsidies and outcomes of educational attainment viz a viz enrolment, retention, transition and equity. The study therefore amplifies the need for the government to streamline the public subsidization policy in view of expectations of sessional paper no 1 of 2005, vision 2030, and the global imperatives namely MDGs and EFA goals.
\end{abstract}

\section{INTRODUCTION}

Since independence, Kenya has expressed the need to attain universal primary education. To demonstrate its conviction, the government ratified the recommendations of the 1990 Jomtien World Conference on Education for All and the Dakar Framework for Action adopted at the 2000 Dakar World Education Forum and endorsed the goals of the Millennium Summit (2000). The Dakar Forum reiterated the right of every child to education and emphasized the duty of the Kenyan government to provide education to all its citizens. Furthermore, the Children's Act of 2001 grants every Kenyan child the right to education. It is therefore incumbent upon the government to take deliberate policy measures and actions to fulfill this obligation (GOK, 2005).

Expanding access to primary schooling is of fundamental importance to the government's development strategy for various reasons. First, universal primary education is central to the implementation of the Poverty Reduction Strategy since the acquisition of basic literacy skills will expand Kenyans access to employment opportunities and sustainable livelihoods. Second, human resource development is key to sustaining the country's economic growth. Kenya's labour force can only participate in the competitive global economy if it has skills that come with education. Third, universal access to primary school education is the most effective strategy for creating equity in education and in opportunities for survival and development (KIPPRA,2008). Ensuring that all children are able to enroll in school presents new opportunities for disadvantaged children, including children from underprivileged regions and communities and girls (World Bank,2008). In the light of the above factors, Kenya government publicly subsidized primary education by implementing the free primary education policy, whose main objectives, according to GOK, (2006) were;

- To reverse the declining enrolments at primary level

- To enhance access, retention, quality and relevance at the primary level

- To improve participation, progression and completion rates at the primary level.

- To implement sector policy goals, including universally accepted conventions on the provision of education (to which Kenya is a signatory)

- To reduce the cost of education, previously borne by parents in the provision of primary school education.

- To streamline and rationalize the use of educational resources

- To implement the provisions of the Children's Act of 2001

- To improve on learning achievements.

In Africa, a number of studies have been done on the impact of government subsidies on educational indices. In Ghana a study by World Bank (2002) noted that after gaining independence in 1957, the government in 1961,made primary school (6 years) and secondary school (4 years) fee free (subsidized) and compulsory. Grade I enrolment increased from 139,000 to 231,000 in the first year and the primary school enrolment increased from 664,332 in 1960 to $1,413,517$ in 1965 , a staggering $113 \%$ increase in 5 years or $16.2 \%$ per year. This resulted in an increase in the GER from 59\% in 1960 to 106\% in 1965. While this high GER resulted from 
the enrolment of many overage pupils, it could be argued that Ghana in 1965 already had an enrolment capacity to cater for all children of primary school age. However, as economic conditions worsened, enrolment stagnated between 1965 and 1970, resulting in a decline in the GER which in 1975 was only $72 \%$ and remained below $80 \%$ until 2000 (UNICEF 2008). It was therefore concluded that there is a positive and significant relationship between government subsidy and enrolment.

Regarding the size of grants, the Ghana study by Volan, (2003) describes 3 findings; First, it suggests the use of two criteria for establishing the amount of money allocated to each school, the first providing an amount proportional to the number of pupils enrolled, and the second providing a fixed amount allocated for each school independent of the size of school because there are many fixed costs largely independent of school size. Second, the size of the grant should be adjusted over time to account for inflation. Third, in most urban areas, the amounts schools receive from the capitation grants is considerably less than the amount they received from the school levies.

In short the potential utility of school grants surpasses their use as an effective mechanism for school fees replacement. School grants can be catalyst for developing capacity, accountability and ownership at the school and community level. Unlike the above studies in Ghana, this study, in addition to enrolment, other indicators of educational achievements like equity, retention and transition are also assessed.

Though it has been established that public subsidy influences either directly or indirectly student enrolment and equity, KIPPRA (2008), cautions that the subsidy faces a number of challenges that include the following;

1) Low transition rates from primary to secondary or to technical, industrial, vocational and entrepreneurship training programs result in high wastage of primary school graduates. The current transition rate stands at 57 percent, denoting a high wastage rate. In the Kenyan context, basic education now means 12 years of continuous learning in school. However, Kenya also faces budgetary constraints so that all standard 8 graduates cannot be transitioned to secondary schools. Expanding access to the secondary level has not taken center stage after FPE.

2) Is the FPE program financially sustainable? In 2006, over 90 percent of FPE funding came from domestic sources; the balance was covered by development partners. The education sector consumes the largest share of the annual government budget (28 percent in 2006). This high allocation must be weighed against competing demands from other critical sectors, including health, physical infrastructure, and agriculture. The need to engage communities and the local private sector is, therefore, urgent.

3) Although introduction of FPE has increased primary-level access and completion rates, expanding access at the secondary level to cater to primary-level graduates remains a major challenge. In 2006, the transition rate from primary to secondary stands at 57 percent. The massive wastage (43 percent) must be amended to guarantee the investment that has been made in free education.

Kenya experienced strong growth in enrolment after independence in 1963 with another surge in 1970s following abolition of school fees in 1974 for grades 1-4, resulting in a near tripling of grade enrolments. In 1978, fees were abolished in grades $5-7$ as well. As a result; Kenya reached a GER of $104 \%$ in 1978 which stayed above $100 \%$ until 1989 . It then declined during a period of economic stagnation to fluctuate at about 90\% during the 1990s until 2002 when it jumped from 88\% to 105\% in 2004 and $112 \%$ in 2005 as a result of abolition of school fees /introduction of subsidy (Gok,2008).

The general purpose of public subsidization of education, in addition to increasing enrolment rates is, as expressed by GoK (2005), UNESCO (2006) and World Bank (2008), to raise primary to secondary transition rate from the $46 \%$ witnessed in Kenya in 2007 to around $90 \%$, and also address the challenges that negatively influence student retention. World Bank (2008) defines transition as the flow of students between different stages in the school system; from one level to the next, between grades within a given level, and out of and back into schools. According to Bondon (1974) the transition through the education system may be described as a series of branching permits at which students may continue schooling, change direction or leave. World Bank (2005) observed that transition from one level to the next depend on the one hand on the availability of school places within realistic reach (geographically and economically) and on the other hand an individual decisions of students and their families. The individual decisions depend on a series of structural factors; students must be adequately prepared from previous schooling and going to school must be considered beneficial both by the individual student, his/her family and the community.

According to Appleton (2001) World Bank (2005, 2008), UNESCO (2006) public subsidy to secondary education should drastically be increased if the education-related MDGs are to be attained. More particularly, to raise primary to secondary transition rate and improve retention, governments must re-allocate more resources to secondary education. Budget allocations to education should increase from current levels of about $3.9 \%$ of GDP across sub-Sahara Africa, especially in countries that receive debt relief. Movement towards 5\% of GDP would improve levels necessary to universalize primary and greatly enhance transition and secondary school enrolment if accompanied by cost-saving reforms (Rudolf, 2002). 
The purpose of this study therefore is to assess the impact of public subsidy on educational outputs, given school inputs and resources in Kenya, a country characterized by relatively higher incidence of poverty among the masses and low GDP growth. The ministry of education, policy makers and other education stakeholders therefore would find this study useful as it informs their decision on the relevant policies to be formulated in view of the public subsidization programme.

\section{OBJECTIVES}

(a) To determine the influence of FDSE subsidy on enrolment

(b) To establish the influence of FDSE subsidy on retention

(c) To assess the influence of FDSE subsidy on transition

(d) To determine the influence of FDSE subsidy on equity

\section{METHODOLOGY}

The research philosophy subscribed to in this study is pragmatism worldview, mixed methods was adopted in collecting and analyzing data rather than subscribing to only one way (e.g., quantitative or qualitative). Thus, in mixed methods research, researcher used both quantitative and qualitative methods because they worked to provide the best understanding of the effectiveness of public subsidy in influencing the critical education indices; enrolment, retention, transition and equity. The target population for this study comprised senior ministry of education and ministry of planning officials, the provincial director of education the district education officers and the school principals of secondary schools in North-rift. North-rift region was chosen because of its geographical diversity; certain parts are ASAL while others are non-ASAL. With this diversity, schools in this region are believed to have varied educational needs and their subsidy demands are also varied.

The research targeted the Permanent Secretaries of the Ministry of Education and the Ministry of Planning, the Rift-Valley Provincial Director of Education and the District Education Officers of the sampled districts using purposive sampling technique. To get the schools to participate in the study and hence the principals, the researcher got a list of all the schools in the Rift-valley Provincial Director of Education office (PDEs) office and the schools' subsidy allocations by type and amount from the government. The researcher used simple random sampling technique to select schools from six counties in the province with a total secondary school population of 493. The study employed questionnaire and interviews to collect data. The collected data was analysed both qualitatively and quantitatively. Qualitative data was analyzed using descriptive statistics like mean standard deviation and the ranges. Descriptive statistics give general opinion with regard to the issuance of subsidy and its influence on educational outcomes. Quantitative data was analysed using inferential statistics. Inferential statistics were used to examine hypotheses of the study. The specific tools that were employed under inferential statistics are t-test and ANOVA.

\section{FINDINGS}

The findings of the study are grounded on the fact that all inputs are resources which are quite scarce. Every allocation of these scarce resources must lead to a commensurate return if such allocation is to be cost-effective and efficient.

\section{INFLUENCE OF SUBSIDIES ON ENROLMENT}

Enrolment is one of the key indicators of educational attainment. It is one of the aspects that have formed the focus of EFA and MDG goals. The findings indicate that a majority of the respondents strongly agree that public subsidy increases class enrolment in secondary schools. This implies that in effect, the subsidy positively influence enrolment. These findings agree with the findings of the study by World Bank (2002) in Ghana that found strong evidence that public subsidies positively influence enrolment at primary and secondary school levels. These findings however disagree with those of Card and Payne, (2002) in USA that found a strong negative relationship between public subsidy and enrolment in post secondary institutions. To support the study position and that of World Bank, (2002), majority of the respondents strongly disagree that government subsidy doesn't affect in any way enrolment. However, majority agreed that there is need to streamline public subsidization programme in the country in terms of enrolment. This may have been informed by the inherent implementation challenges. For policy purposes, respondents were asked their views on the need to streamline public subsidization programme in the country in terms of enrolment, majority of the respondents agreed on the need to streamline this programme. This implies that, to attain the intended goal of raising enrolment and meeting the MDG and EFA goals, the policy markers at both local and national level together with the other players in education must develop policies that streamline the subsidy implementation and hence 
raising enrolment. They should be cognizant of the fact that the enrolment needs of ASAL and non-ASAL areas are different.

\section{INFLUENCE OF FDSE SUBSIDY ON RETENTION}

Retention has been a major challenge in both developed and developing world (Psacharapoulos and Woodhall 1985). In Kenya, one of the issues that the country must address is the challenge of low secondary school retention (KIPPRA 2008). The introduction of public subsidy was intended to address this challenge. The research investigated the influence of FDSE subsidy on student retention in secondary schools. Majority of the respondents strongly agreed that public subsidy increases student retention. This implies that public subsidy increases student retention in schools. The respondents strongly agreed that due to the inherent challenges facing the public subsidization programme in the country, there is need to streamline it to bring about the desired outcome in terms of student retention. Majority of the respondents either strongly agreed or agreed that public subsidy increases student retention in secondary schools. This implies that there is a positive relationship between government subsidy and retention. These findings support the position of World Bank (2008), Lewin (2008) and UNICEF (2008) that investment in basic education would guarantee steady retention of students in school. UNESCO (2005) in a study in Cameroon added that a sustained effort by the government to raise student retention in schools call for a re examination of budgetary allocation in favour of basic education.

On the need to streamline the subsidy, majority of the respondents agreed that there is need to streamline the programme in the country to bring out the desired outcome in terms of student retention. This implies that whereas the subsidy has the potential of enhancing student retention, there are certain hurdles that hinder the realization of maximum student retention in the light of the subsidy.

\section{INFLUENCE OF FDSE SUBSIDY ON TRANSITION}

Transition rate from primary to secondary level has been the concern of all education stakeholders in the country (KIPPRA, 2008). The research investigated the influence of FDSE subsidy on transition in six counties of North-Rift. Majority of the respondents agreed that public subsidy increases transition rate from one level to the next. This implies that in the opinion of the respondents public subsidy positively influences transition rate. Majority of the respondents agreed that there is need to streamline public subsidization programme in the country to improve student transition. On the need to streamline the public subsidy programme to raise transition, respondents were almost unanimous that there is such an urgent need. The policy makers therefore have a duty to look into the programme and address all the concerns that have been raised by the key players in education.

\section{INFLUENCE OF GOVERNMENT SUBSIDY ON EQUITY}

Equity has remained a central concern to most education stakeholders. The Kenya government, while formulating any policy, places equity considerations first (KIPPRA, 2008). The research investigated the influence of government subsidy on equity in education and found out that majority of the respondents in the study area agreed to the statement that public subsidy ensures all students from poor households get enrolled and retained in schools. Subsidy ensures students in ASAL areas benefit from education and it also ensures that both male and female and children with special needs receive education. The implications of these findings are that the subsidy has achieved its original mission and objective of ensuring equity and fairness in the provision of education in the country. Public subsidy ensures all students from poor households get enrolled and retained in secondary schools. This finding is in line with EFA and MDG goals. Ideally, the purpose of any subsidy is to target the child from poor socio-economic background and ensure that, that child get enrolled and retailed in school (G.O.K, 2005).

\section{RECOMMENDATIONS}

1. To attain the EFA and MDG goals by the year 2015 in Kenya, it is recommended that the government should streamline the FDSE policy to be sensitive to the needs of ASAL areas and other most-vulnerable groups in the society.

2. The government should develop a comprehensive training programme for all direct-line service provides in education (teachers, principals, education officers, QUASOs, PDEs etc) to equip them with implementation skills to aid in the realization of FDSE subsidy goals. 


\section{REFERENCES}

[1] Appleton, S. (2001). "What Can We Expect of Universal Primary Education?” In Uganda's Recovery: The Role of Firms, Farms and Government, ed. R. Reinikka and P. Collier. Washington, DC: World Bank.

[2] Card D.A, \& Payne A. A. (2002). School finance reform, the distribution of school spending, and the distribution of student test scores. Journal of Public Economics 83 49-82

[3] Government of Kenya (2005). Sessional Paper No. 1 of 2005 on A Policy Framework for Education, Training and Research. Nairobi: Government Printer.

[4] Government of Kenya (2006). Education sector report 2006 Report. Retrieved January $\quad 20, \quad 2007$, from http://www.treasury.go.ke

[5] KIPPRA (2008). Public Expenditure Tracking of Secondary Education Bursary Fund in Nairobi Province, Kenya at http://www.ipar.or.ke

[6] Lewin K M (2008). Strategies for Sustainable Financing of Secondary Education in Sub- Saharan Africa. Africa Human Development Series. Working Paper No 136. World Bank, Washington

[7] Psacharapoulos, G. \& Woodhall, M. (1985). Education for Development; An Analysis of Investment Choices, Washington D. C. World Bank.

[8] UNESCO (2005). EFA Global Monitoring Report. UNESCO; Paris.

[9] UNESCO (2006). Global education digest: Comparing education statistics across the world. Montreal: UNESCO Institute for Statistics.

[10] Volan, S. (2003): Educational Reforms and Change in the South. Doctoral Thesis, Universityof Southampton.

[11] World Bank (2002) Education and HIV/AIDS: A Window of Hope World Bank, Washington DC

[12] World Bank (2005). Expanding Opportunities and Building Competencies for Young People: New Agenda for Secondary Education. Washington, DC: World Bank.

[13] World Bank (2008). World Development Indicators 2008-09. Washington DC. World Bank 